\title{
An Ivory Tower in Archaeology? A Conversation with Leo S. Klejn
}

\section{Mats Burström}

\begin{abstract}
During a conversation between Professor Leo S. Klejn from St. Petersburg in Russia and the author some controversial issues were discussed. These include aspects of feminist and gender archaeology, the nature and function of archaeological theory, the separation of archaeology and prehistory as scholarly disciplines, and the relation between archaeology and contemporary society. The latter issue leads to the question of whether or not we as archaeologists ought to build ourselves an ivory tower.
\end{abstract}

Mats Burström, Department of Archaeology, Stockholm University, S-106 91 Stockholm, Sweden.

In the autumn of 1992 Professor Leo S. Klejn from St. Petersburg in Russia visited Sweden. In Sweden Klejn is probably most associated with the monograph Archaeological Typology (1982) and the article $A$ panorama of theoretical archaeology (1977; in Current Anthropology). The latter is a survey and analysis of the theoretical debate in archaeology, covering a period of more than ten years up to and including 1973. Klejn has, however, published works in a large number of subjects, and outside the English-speaking countries he is associated mainly with other themes.

During Professor Klejn's stay in Sweden a broad repertoire of subjects were discussed. Because of Klejn's often radical - or, if you like, reactionary - opinions the discussions came to follow partly unexpected paths. Some of the issues that were in focus during these discussions were touched upon during a lunch-conversation on a wintry Octoberday in Stockholm.

The other day you had a meeting with a group of prominent Swedish archaeologists, including the director-general of the Central Board of National Antiquities (Sw. Riks- antikvarien) and the heads of the archaeological university-departments. In the invitation to this meeting you were presented as one of the internationally legendary archaeologists. What do you have to say about this legendary status?

- A provocative question. To read so high an estimation declared by such an authoritative board of professionals is something that can make anybody shocked. And proud. But let us try to understand the words in their exact, narrow meaning. If being "legendary" simply means to be a man who is much talked about but whom most people have not seen, then the wording is $\mathrm{OK}$ because for some decades I was not allowed to go abroad.

- If, however, "legendary" should be understood as "glorious" or "famous," then I have to stress that Sweden has some extraordinary archaeologists who are legendary in Russia. One of them is, of course, Mats P. Malmer.

You are one of the few non-Scandinavian archaeologists who have discussed Malmer's work in relation to the international debate that took place during the 1960 s and 1970s. 
What is your view on Malmer's contribution to that debate?

- Many features of the New Archaeology were advanced in two works: one American (Lewis R. Binford's Archaeology as Anthropology) and one Swedish (Mats P. Malmer's Jungneolithische Studien), both published in 1962. However, the American contribution was a little article without concrete elaboration, while the Swedish one was a gigantic monograph based on a vast amount of archaeological material and full of specific propositions in archaeological theory and methods. Later, in 1968, another big monograph of the New Archaeology appeared in England (David L. Clarke's Analytical Archaeology) but its geograhical and typological aspects were already anticipated by Malmer.

- I don't want to diminish Binford's and Clarke's roles, their right to be considered as the leaders. But justice must be done. True, processual aspects of the New Archaeology were proposed by Binford and Clarke, not by Malmer. But then let us not forget that from the time of Montelius the typological method was not changed, not developed, and even had lost its credit in archaeology and began to be used in inappropriate ways, without strict rules. In fact it degenerated. Malmer has not only restored its implementation and strength but improved it considerably; he has found fundamentally new possibilities in it and, thus, widened its applicability. He made the method applicable in situations where sealed or stratigraphic finds are absent. Montelius was called the King of Archaeology. The evolutionary-typological method is the most specifically archaeological of all methods. So, in developing the specifically archaeological method Malmer is second after Montelius. Not a bad place in the history of archaeology!

- Many years ago I wrote a book in Russia on Malmer's teaching and results, but like many of my manuscripts it remains unpublished.

Why is that?

- For several reasons. The author - I mean me - was not in favour. The subject matter - I mean Malmer - was not promising; not a Russian, not a Marxist. And in general it was difficult to be published on archaeological matters in Russia. Yet, in manuscript form it was used by me in teaching many generations of archaeologists at Leningrad University.

During this journey you have visited the archaeological university-departments in Lund, Göteborg, Stockholm and Uppsala in Sweden and Oslo in Norway. What is your general impression of current Swedish archaeology?

- I am here too short a time and Swedish literature doesn't often reach Russia today; so just now I can make only surface observations. Mainly about differences from Russian archaeology, but they are obvious. Rich technical equipment and installations, much space for archaeological studies - I mean real space, plenty of large rooms. Many publications, all of very good graphical quality. Graduate students in archaeology are numerous, more than in Russian universities, and their average age is generally higher than Russian students.

- Like in Russia there are a lot of women in archaeology, but in general women here have higher positions in science (director-general of the Central Board of National Antiquities [Sw. Riksantikvarien] and two vice chancellors [Sw. universitetsrektor], in Lund and Umeå. Also in Oslo there was a female vice chancellor).

Speaking of women's positions, what is your opinon on feminist and gender archaeology? 
- To me, feminist and gender archaeology is something new and odd. As yet it is completely absent in the former Soviet territories. The interest in the position of women in the society of the past, women's role in evolution, and women's contribution to culture is of course quite natural and must be fruitful. The trend is understandable in the contemporary situation. However, I consider the label of this trend to be erroneous. Strictly speaking, the trend does not belong to archaeology. Rather it belongs to prehistory, or, more broadly, to paleohistory. Because to reveal the role of women in society means to make historical judgements. It would be silly to divide archaeology according to gender (of the students? of the ancient graves?) into a feminist one, a masculine (or male-chauvinist?) one, a childish one, a homosexual one...

- It would be disastrous to develop different criteria for studying male graves and female graves, or for estimating male monographs and female monographs. Nonsense! And in no case is it a theoretical movement. It deals with the discovery of some facts. With statements of facts. With generalizations of facts. But generalization is still not theory.

What is theory, then? And what is its purpose?

- These are the crucial questions in theoretical archaeology. One has to begin with them. From my early steps I encountered them, too.

- Usually when I begin studying a theoretical problem, I first look around to see what is already done, what opinions have been advanced by several archaeologists. Then I try to understand the root of differences in opinion. Rarely in serious works are propositions completely wrong. Usually they are one-sided but contain some grain of truth. So I try to see if it is possible to find a common base in the diverse suggestions, to make a generalization. Sometimes (not always) it is possible. I try to define the philosophical basis of each individual conception. And then I try to comprehend my own basis, my own way.

- With regard to the questions you have put to me, I made a survey of many conceptions advanced by Western archaeologists and by the Soviet ones. The views appear to be very different: theory is just speculation, or generalization of facts, or a set of methods, and so on. I came to the conclusion that theory is all of this, but such a conclusion is too general. Beneath this summation there must be something specific which is responsible for all these implementations, and which is connected with the notion of theory in other disciplines. What this is, is a complicated matter to analyse and it isn't possible to explain in short.

- The lectures I have prepared for this visit, however, are devoted to these subjects: the definition of archaeological theory, a survey of existing conceptions of it, and the functions of archaeological theory.

You mean purposes of archaeological theory?

- Purposes, aims, tasks, functions - the sense is one. Glyn Isaac formulated it so: Why do we need to bother with theory? This is the question which many practical archaeologists put to the theoreticians, quite often with the implication that in fact we needn't bother. So the theoreticians should give the answer to this question. To my surprise I found only a few works on this subject in archaeological literature. Recently I wrote a special article on this matter (still not published) and entitled it Functions of archaeological theory. I prefered this term because the implication is that we must reveal not only the purposes of theory but also how theory works. Or at least show the way to the latter. Ultimately it is necessary 
for the answer to the first question to be convincible.

The most unexpected and incomprehensible for many of your Western readers is perhaps your insisting on the separation of archaeology and prehistory as scholarly disciplines. What are your motives for this separation?

- This was the main point of my theoretical studies during many years, beginning with the article Subject matter of archaeology (1977) and the book Archaeological sources (Russian edit. 1978, Slovenien 1987) and ending with the very last articles To dissect Centaur (Russian edit. 1991, Spanish 1992, English 1993) and Historicism in archaeology (Russian edit. 1993).

- This side of my activity is scarcely reflected in my publications in English and therefore remains nearly unknown in the West. Meanwhile, in Russia, reviews and responses on the book Archaeological sources still continue to appear, after 15 years! I have had long and sharp polemics concerning this book with some of my Russian colleagues.

What are the main points in the book and why is it so controversial in Russia?

- I suspect not only in Russia but in Russia especially. Insisting that archaeology must be considered as an independent discipline with its own theory and methods, was aimed against the official Soviet view of archaeology as a part of history, namely, its initial section dealing with the most remote past. That view implied that archaeology needn't have a separate theory or a special set of interpretative methods. Ideological guidelines set by Marxist philosophy for the humanities would suffice. Plus the ordinary common sense usually used in history.

- I proclaimed the revolt against this dogma, and thus against misusing archaeology for ideological and political needs. Archaeology is archaeology is archaeology, pace David Clarke. Yet Clarke did not distinguish between prehistoric archaeology and prehistory - they meant the same to him. I go further in establishing the independence of archaeology.

You mean that prehistory and prehistoric archaeology should be considered separate disciplines?

- Yes, of course. They don't deal with the same material or the same methods.

- Archaeology has to process material remains of the cultural past, process them as sources of information on the past events and processes, while history and prehistory consider just the events and processes of the past and try to reveal their causes and moving forces. So archaeology is one of the source-studying disciplines that serve or, if you like, cooperate with, history and prehistory.

So you separate the study of sources from their interpretation. Isn't such a separation harmful to archaeology?

- Rather, I would say that the processing of material sources must be separated from their use in historical studies. To which of these disciplines interpretation belongs, is a more complicated problem.

- If interpretation is regarded as the translation from the language of things into the language of historical description, the interpretation still belongs to archaeology. It is the archaeologist who has the task to reconstruct events issuing from things. Events and some processes. However, to judge by the adjacent events (to reconstruct unknown events issuing from known events) and to reveal their causes, to build the entire picture of the past society in its dynamics, is the domain of history. Correspondingly, 
the domain of prehistory if it deals with the more remote past.

But why divide this continuous process of study into two separate stages, why separate it into two different disciplines? Why not allow professionals to be both archaeologists and prehistorians?

- Because these two spheres have very different tasks; they need fundamentally different competence, different sets of methods. In our time of specialization, time of extreme sophistication and detailed development of disciplines, it would be odd to insist on joining different skills together. It would mean a loss of professionalism.

- An archaeologist is the specialist in processing one kind of source, namely, material traces and remains of the past. History cannot be written on the basis of merely one kind of source, because like all single sources it is one-sided and incomplete, usually fragmented and full of gaps. History (or prehistory) needs to synthesize all kinds of sources - written ones, ethnographical, anthropological, linguistic and so on. This synthesis is outside the competence of an archaeologist. It is too much for one person.

- A historian (or prehistorian) takes the results of various source-studying disciplines (archaeology, palaeoanthropology, ethnography, palaeography, numismatics and so on) and combines them in order to obtain the answers to his specific questions, to obtain the entire picture of the past. And the methods of interdisciplinary synthesis are special kinds of methods.

- So my position implies not only the establishing of archaeology as a separate discipline but also establishing prehistory as a self-dependent discipline, separated from prehistoric archaeology. The merging of both is not in favour of either. It leads to confusion of concepts and methods and to insufficient development of either discipline.
Is your own practice really in accordance with this theoretical standpoint?

- You have got me there. I can't object, there is a contradiction here. Or rather, I'm forced to admit the contradiction if I don't want to be immodest and say that I'm an exception because of my extraordinary abilities. No, I am not an exception. I have been practising both archaeology and prehistory indeed. I have also made some studies in philology (Homeric studies), political journalism and the theory of music. Yet it does not mean that they all can be united into one profession. Neither can archaeology and prehistory. I practised them as different professions, as additional professions, each one according to its own rules.

- Sometimes it is useful to change specialization or even profession. Pasteur did this more than once and achieved success in each. But of course this is a risky affair and one must feel responsible enough to work in a new discipline on a professional level. One must feel strong enough, ready to undertake this. I cannot recommend this to everyone. It is safer to be a master in your own profession.

If archaeology as a discipline is supposed to be concerned only with systematization and classification of the archaeological source material and not include any "historical" interpretations, will it still be possible to motivate people to conduct archaeology?

- Never fear. Interests that lead people to archaeology are surely variable. Some people are attracted by expeditions, excavations, romance and the mysterious atmosphere of ancient things. Others are enthusiastic about modern technical means. There are also people who are eager to classify, collect, build beautiful typological schemes. It is by no means a common trend 
to be engaged in processual archaeology which to me is not archaeology at all. Instead it is a sort of prehistory or rather cultural palaeoanthropology. At least in its initial form.

But processual archaeology is a considerable stage in the contemporary history of archaeology, isn't it?

- Certainly. So what? There were times in the history of archaeology when it was just a branch of geography, in Soviet scholarship it was considered a part of history...

Was?

- I hope so. In fact it still is, but this is a time of change and the Soviet period is over.

Some post-processual archaeologists deny the possibility of evaluating the credibility of prehistorical interpretations against archaeological sources. Instead all interpretations are supposed to be governed by the theoretical framework, and the only way to choose between different pasts is said to be political. What is your view on this?

- There is some confusion in the very basis of these so-called post-processual suggestions. To trace the ideological and social roots of some archaeological conclusion, theory or trend is a prospective thing, and Marxism, if applied carefully, can be helpful here. But it would be sheer craziness to think that this is the only source of archaeological constructions.

- Even in the most one-sided, unsubstantiated or queer archaeological constructions made by professionals (we make these more often than we want to), there is usually some contact with firm facts, there is something sure and stable. One must only separate this out. On the other hand, even in the most profound, proved and well established theories one may find reflections of some ideological influences, of social myths. It must not make us desperate. It does not mean that our knowledge is completely dependent on ideology and politics, that it has to be connected with them and that the only way out is to choose a good ideology, a good policy to introduce into archaeology. Merely that one must be careful, that's all.

- Yes, we know that our conclusions are more or less under the influence of ideology, politics and the like. However, the way out is in elaborating the means to annihilate this influence, in elaborating criteria and methods of checking our conclusions against facts. This is the essence of science and every scholarly knowledge.

What, then, would be the ideal situation for archaeology's relation to contemporary society? Shall we build ourselves an ivory tower? Is a non-political archaeology possible?

- "Ideal situation" is an apt phrase. It means that we have in mind a norm we orient our activity upon, even if we know that in pure form it is unachievable. Maybe the non-political archaeology, nonideological archaeology, is impossible (in its pure, ideal form) but it is the norm we must strive towards.

- To build an ivory tower called "archaeology" and close ourselves within it, away from the outside world, is impossible and unnecessary. Yet every archaeologist must have in his mind an ivory tower as an ideal upon which concrete construction can be checked and shaped. To me, the general theory of archaeology builds just such an ivory tower.

English revised by Laura Wrang 